The Transfer of Human Resource Management Systems Overseas: An Exploratory Study of Japanese and American Maquiladoras

Schon Beechler

Sully Taylor

Working Paper No. 68

\author{
Professor Schon Beechler \\ Assistant Professor \\ Management of Organizations Division \\ Graduate School of Business \\ Columbia University \\ New York, NY 10027
}

\author{
Sully Taylor \\ Assistant Professor \\ International Management \\ School of Business Administration \\ Portland State University \\ Portland, OR 97027
}

Working Paper Series

Center on Japanese Economy and Business

Graduate School of Business

Columbia University

October 1992 


\title{
THE TRANSFER OF HUMAN RESOURCE MANAGEMENT SYSTEMS \\ OVERSEAS: AN EXPLORATORY STUDY OF \\ JAPANESE AND AMERICAN MAQUILADORAS
}

\begin{abstract}
The field of international management has, until recently, largely ignored how human resources management (HRM) systems in overseas subsidiaries are designed and how design impacts performance. In addition, there is virtually no research comparing the HRM systems in Japanese and Western affiliates.

In an attempt to begin to address this important issue, this chapter presents the results of a study of Japanese and American maquiladoras (in-bond assembly plants) in Mexico. The research builds on two streams of recent work in the international management field - the first on international human resource management systems and the second on strategic roles of business units in MNCs.

This chapter examines the relative influence of parent company strategy, strategic role of the affiliate, parent company administrative heritage, and host country environment on the HRM systems in eight maquiladoras, four Japanese and four American, located in Tijuana, Mexico. Using a contingency framework, this chapter also describes the fits between each maquiladora's HRM system and its internal and external environments. Finally, it identifies
\end{abstract}


the resulting impact of these fits on performance, both at the individual employee and affiliate levels. 


\section{Biographical information on the authors:}

Schon Beechler is Assistant Professor of Management and International Management, Graduate School of Business, Columbia University. Dr. Beechler received her PhD in Business Administration and Sociology from the University of Michigan and her B.A. in Sociology and Anthropology from Oberlin College.

Dr. Beechler was the recipient of the Fulbright Research Fellowship in Tokyo, Japan from 1986 to 1988. She has conducted research on the management and strategies of Japanese affiliates in Southeast Asia and Europe and is currently researching management practices at Japanese, other Asian, and American affiliates in Mexico and in eight countries in Southeast and East Asia.

Sully Taylor is Assistant Professor of International Management, School of Business Administration, Portland State University. Dr. Taylor received her PhD in Business Administration from the University of Washington, and her B.A. in Latin-American History from Southern Methodist University.

Dr. Taylor conducted her dissertation research on R\&D management in Japan as a Fulbright Research Fellow in 1988. She has conducted research on international HRM systems in MNCs operating in Mexico, Europe and the U.S., and also conducts research on the transfer of Japanese management abroad. 


\section{Introduction}

As the final decade of the 20th century unfolds, global economic players from industrialized and newly industrializing countries alike dominate the world's economic landscape. Perhaps one of the most visible and formidable changes to this landscape has been the sudden arrival and powerful presence of Japanese multinational firms.

Although most Japanese firms did not begin internationalizing their operations until after World War II, Japanese multinational corporations (MNCs) have evolved through a number of stages of overseas involvement since the end of the second World War. From the 1950's until the mid1960's, Japanese MNCs were mainly exporters of finished goods from Japan. Overseas investments were made primarily in order to obtain raw materials, such as coal, timber, etc. Then, as the Japanese economic miracle took off in the $1960^{\prime}$ 's and labor costs began to rise, manufacturers were forced to look overseas for cheaper labor to help reduce costs in order to sustain sales of Japanese goods. Japanese MNCs moved from an export-oriented stage of overseas involvement to a second stage of investment in laborintensive assembly operations, primarily in Southeast Asia.

In addition to building assembly plants in southeast Asia, Japanese MNCs began to establish sales offices in the 
United states and Europe in this second stage in order to increase product sales in these large and important markets. This pattern of Japanese overseas investment continued until the late 1970's when the anemic economic performance of the Western countries resulted in increasing political pressure and threats of protectionism against Japanese exports unless Japanese firms agreed to establish production plants in these countries. These changes resulted in a shift in Japanese corporate strategy and the transition to a third stage of Japanese overseas involvement -- localization of production. Transferring production from Japanese to overseas sites served not only the interests of Westerners but also those of Japanese MNCs since these firms were simultaneously experiencing ever-higher manufacturing costs at home, particularly after the yen revaluation which resulted from the Plaza Accord of 1986.

Today, continued political pressures and the creation of regional economic blocks, as well as scare and expensive labor at home continue to drive Japanese foreign direct investments in a number of areas, including the United States, Europe, and Mexico. One important area to receive keen attention from Japanese firms has been the Mexican maquiladora industry which offers low labor costs and easy access to the American market. At the same time, however, the maquiladora industry presents a number of complex and difficult challenges for managers of these firms. This 
chapter reports the results from an intensive research study of eight maquiladoras, four Japanese and four American, and focuses on the human resource management challenges facing these firms.

\section{The Maquiladora Industry}

Maquiladoras are in-bond assembly plants located inside Mexico, usually along the border with the United states, the most important market for Japan. These plants have several significant advantages from the Japanese point of view. Manufacturers are allowed to send raw materials, parts or equipment into Mexico duty-free, as long as the finished products are exported. There are no local content requirements on maquiladora goods manufactured for export and manufacturers must pay import duty on only the value added to the product in Mexico (Teagarden, Butler, \& Von Glinow, 1992). The low tariffs, low cost of Mexican labor, averaging approximately $\$ 1.63$ per hour (Businessweek, November 12,1990 ), along with a relatively high literacy rate and plentiful and young workforce, are attractive to MNCs in industries such as electronics, woodworking, garments, and automobiles where there is severe global price competition. These factors allow Japanese MNCs to avoid the full cost of locating production in the U.S. While still reaping most of the benefits. Moreover, because the goods 
are produced in Mexico, they are not counted against Japan's total allocation in those product classes which are subject to import quotas.

From a handful of assembly plants in the mid-1960s, maquiladoras now number over 1900, employ over 500,000 workers, and provide Mexico with its second-largest source of income. Although almost all of the investments in the maquiladora industry before 1986 were made by American firms, in recent years the positive factors cited above have led to major Japanese investments in the maquiladoras. It is estimated that there are currently 200 Japanese maquiladoras, out of a total of approximately 1900 firms (Teagarden, et al., 1992), and although Japanese firms make up only one-ninth of the total number of firms, because of their relatively larger size, Japanese maquiladoras represent approximately $15 \%$ of total employment in the maquiladoras (Scott and Oseghale, 1990).

The Mexican maquiladora industry represents not just a present, but also a future potential benefit to Japanese MNCs. With the increasing likelihood of the passage of the North American Free Trade Agreement, an investment in Mexico will continue to provide labor cost advantages for the medium-term while opening up an even larger market including not only the United States and Mexico, but Canada, as well. There is also the possible addition of South American countries, such as Chile, to the Agreement, which would 
expand the potential market for output from the maquiladoras. In the interim, these maquiladoras can serve as listening posts for the booming South American economies, as well as provide crucial experience in managing LatinAmericans.

The maquiladora industry of Mexico is therefore an important and increasingly strategic low-wage assembly platform for a growing number of firms from higher-wage countries, such as the United States, Germany and Japan, which face increased price competition from manufacturers from Thailand, Malaysia and other low-wage countries. In addition, the maquiladora industry presents an opportunity for foreign firms with operations in Mexico to expand and grow with the increasing economic development and integration of the region.

However, although Mexico may provide a safe haven from the spiraling wage costs at home and a strategic opportunity for the future, MNCs must contend with numerous obstacles to efficient production, including the management of the local workforce. The maquiladoras can represent a difficult and hostile environment where labor turnover, particularly along the border, is extremely high and labor-management relations in the past have been distant. In addition, many workers in the maquiladoras are from remote agricultural villages and have no prior industrial experience or skills. Workers often hold negative stereotypes about foreigners (e.g., 
Americans) and have little knowledge about Asia, including Japan, or Asian management.

Within this environmental context, there are essentially two approaches which MNCs can adopt in managing their maquiladora labor force: 1. adapt to the local practices, or 2. transfer the parent company's human resource management (HRM) system overseas. Each approach has strengths and weaknesses, as shown by a number of writers (e.g., Adler, 1991; Milliman, et al., 1991). Although a number of authors in international business have examined the transfer of management policies and practices overseas yet there has been very little empirical research which looks at why firms choose to either export or adapt to the local environment. In addition, in spite of both the importance of Japanese and American investments in the maquiladora industry, there is a paucity of research on the management of these firms (Taylor, Beechler \& Moxon, 1991).

The research reported in this chapter begins to address this gap in our knowledge. In the following section we present a theoretical framework developed to guide this research effort. We then present results from our research, explicitly addressing the theoretical propositions presented in the theoretical discussion. In addition to exploring the general characteristics of the HRM systems of each of the eight maquiladoras, we also address the issue of why a particular firm does or does not transfer its parent company 
policies and practices overseas and whether affiliate and individual performance are affected.

\section{Theoretical Framework}

organizations gain and sustain competitive advantage by capitalizing on their strengths -- their distinctive competencies (Selznick, 1953). There are two basic types of distinctive competencies in organizations: technological and managerial know-how (Caves, 1982). Technological know-how consists of $R \& D$ and production while managerial know-how consists of finance, marketing, and human resource management. The last of these, human resource management, has only recently been thought of as a managerial competence. There is increasing recognition, however, that HRM is an area that can contribute greatly to a firm's competitiveness (Evans, 1986; Pucik, 1985; Napier, 1990; Butler, Ferris \& Napier, 1990; Schneider, 1990; Ulrich and Lake, 1990; Bird, Beechler \& Raghuram, 1991).

There are three different components of an HRM system -- philosophy, policies, and practices. HRM philosophy is the prevailing beliefs and attitudes held by management concerning human nature and the nature of the employment relationship (Bird, Beechler and Raghuram, 1991). HRM policies can be thought of as decision rules: procedures 
that organization members are expected to follow. Practices are less formal than policies and can be thought of as the actual decisions taken by organization members. Practices thus reflect those policies that are actually carried out (Bird, Beechler and Raghuram, 1991).

For example, many large Japanese MNCs have a philosophy of "lifetime employment" vis a vis their core workers, and institute certain HRM policies which provide employment security from the time the employee is hired until he retires at age 55 or 60 , even though that employment may be in a subsidiary firm (Inohara, 1990). Supporting HRM policies include selection procedures that focus on the personality fit of the candidate with the firm rather than immediate skills, and the promotion of internal candidates to open positions. The actual selection procedures (tests, interview, and selection criteria, for example) as well as actual promotion decisions, on the other hand, represent practices.

The HRM system includes the functions of recruitment, selection, appraisal, compensation, training, and career development. These functions represent an important source of distinctive competence because they influence the firm's ability to attract, motivate, and retain the kinds of workers it needs - its overall HRM success (Schneider and Schmitt, 1986). The greater the firm's reliance on its human resources as a source of competitive advantage, the 
more important HRM success will be to the overall success of the firm as a whole.

Although $\mathrm{HRM}$ has been explicitly recognized as a key competency by a few authors writing about domestic operations, most prior work on distinctive competencies in multinational corporations has focused on the utilization of the MNC's technological competencies by its foreign subsidiaries (e.g., Ghoshal and Bartlett, 1988). However, both technological and managerial know-how can be transferred overseas (Caves, 1982). Thus, the transfer and/or the local development of HRM systems in overseas affiliates can represent a key competence for multinational corporations.

In developing propositions about the transfer of HRM overseas, we use contingency assumptions to make predictions concerning the design of the affiliate's HRM system, given certain specified contingencies. Although there are a number of different approaches in contingency theory, we adopt a systems approach as it is the most comprehensive and also recognizes that the design of an organizational system must meet two often conflicting criteria: the outside contingencies facing the firm and the need to be internally consistent (Van de Ven and Drazin, 1985). Thus, a systems approach allows use to acknowledge the conflicting demands on MNC systems which have been highlighted by a number of recent authors writing about MNCs (e.g., Doz, 1986; 
Bartlett, 1986; Bartlett and Ghoshal, 1989; Rosenzweig and Singh, 1991).

There are two often conflicting demands on the overseas affiliate: demands for internal consistency with the rest of the firm and demands for external consistency with the local environment (Adler, 1991; Milliman et al., 1991; Rosenzweig and Singh, 1991). Since clashes between the external and internal environments can inhibit organizational functioning at every level and in every functional area within the firm, management must resolve these conflicting demands in order to reach their organizational objectives. In designing and implementing an HRM system for an overseas affiliate, management must attempt to resolve these tensions to meet organizational, local environment, and internal consistency demands.

In designing the HRM system for an overseas affiliate, the parent company may attempt to create HRM philosophies, policies or practices that reflect local values (high external consistency), it may attempt to transfer the parent firm's corporate HRM system overseas (high internal consistency), or develop and implement a world-wide HRM system which combines both the characteristics of the parent company's HRM system and those of its overseas affiliates around the world (high internal consistency and moderate external consistency) (Bartlett and Ghoshal, 1989). Although it is important to acknowledge these three 
possibilities theoretically, because we have not gathered data at HQs or other subsidiaries of the MNCs in our sample, we cannot address the third possibility, the transfer of affiliate policies and practices to the rest of the MNC, but focus our attention here on the question of whether the MNC transfers parent company practices and policies overseas or adopts local practices and policies.

Parent Company Characteristics

There are two primary categories of variables which influence the design of an overseas affiliate's HRM system: parent company characteristics and local environmental characteristics. The first of these, parent company characteristics, includes the overall strategy of the firm, the level of interdependence between the parent company and the affiliate, and the MNC's administrative history.

MNC strategy

At the business level, MNCs can orient themselves with regard to cost versus differentiation strategies (Porter, 1986). A firm that follows a strategy of cost leadership seeks to achieve competitive advantage by being the 
least-cost producer of a product. Porter (1986) notes that a cost leadership strategy requires a firm to focus on functional policies. Under a cost leadership strategy, internal operations of the firm are driven by efficiency considerations. A cost strategy leads MNCs to establish tight cost controls, require frequent reports, enforce strict rules, and establish incentives based on quantitative methods.

By contrast, when a firm adopts a differentiation strategy, it seeks competitive advantage by providing unique value to a product (Porter, 1986). Firms are less concerned with cost and more concerned with identifying what special value they are able to add. A differentiation strategy forces a firm to develop an external focus, to be intimately aware of what its customers desire. This strategy requires an emphasis on coordination, incentives based on qualitative methods, and the maintenance of quality and technological leadership.

Those MNCs that are seeking to differentiate their products on a global basis are concerned that their product characteristics of interest to consumers be salient across the markets they serve. In order to follow a differentiation strategy, the firm depends on the involvement and commitment of the people involved in production in order to create a product with salient characteristics and will therefore be likely to transfer key 
successful HRM policies and practices from the HQs to its overseas affiliate to sustain its competitive advantage.

Compared to firms following a differentiation strategy, MNCs following a low cost strategy are more concerned with output measures, particularly productivity (Porter, 1986). These firms are therefore more concerned that the affiliate keeps the cost of human resources as low as possible rather than managing people through a common set of HRM practices and policies. Thus, all else equal, firms following a differentiation strategy will be more likely than firms following a low-cost strategy to transfer parent company HRM system to their overseas affiliates:

Proposition 1: MNCs following a differentiation strategy will be more likely to transfer the HRM system of the parent company to their overseas affiliates than will MNCs following a cost strategy.

Although business-level strategy can help predict whether MNCs will transfer their HRM system overseas, it is also necessary to examine strategy at the subunit level since there are conflicting pulls between internal and external environmental forces on the affiliate's HRM system. For example, although MNCs can be characterized as following either a multidomestic or global strategy at the corporate level (Porter, 1986) or a low-cost or differentiation strategy at the business level (Porter, 1986), affiliates within a single MNC, and even within a single business line, 
may play different roles within a particular strategy (Gupta and Govindarajan, 1991).

A number of typologies characterizing different roles for overseas affiliates have been proposed in the literature (e.g., Bartlett and Ghoshal, 1989). One important dimension which is expected to influence the level of consistency of HRM systems is the degree of interdependence between the activities of the parent company and the particular overseas affiliate. Interdependence is determined by both the volume and the direction of resource flows between organizational subunits (Gupta and Govindarajan, 1991). Although interdependence is no doubt greater in firms following a global strategy than a multidomestic one (Bartlett and Ghoshal, 1989), within a single MNC, there are different levels of interdependence between the parent and its various overseas affiliates (Gupta and Govindarajan, 1991).

The nature of the resource flows between the parent company and its overseas affiliates is important in understanding the transfer of HRM overseas because resource flows determine the need for coordination and control mechanisms to manage the resulting interdependence (Pfeffer and Salancik, 1978). Although ownership patterns and financial controls have been the focus of most research in this area, the HRM system presents an important means to manage the interdependence between the overseas affiliate and the parent firm. The parent firm relies on individuals, 
in addition to policies and practices, to ensure that needed human resources are hired, developed, and compensated so that the employees' behavior will lead to the results desired by the firm in order to implement its strategy. The higher the level of interdependence between the parent firm and the overseas affiliate, the greater the likelihood that the parent firm will transfer its HRM system overseas to its affiliate since, generally speaking, both coordination and control functions are facilitated by standardization:

Proposition 2: The higher the interdependence between the parent company and the overseas affiliate, the more likely the parent company will transfer its HRM system to its overseas affiliate.

Administrative Heritage

Another important characteristic of the parent firm is its administrative heritage (Bartlett and Ghoshal, 1989). The administrative heritage of a MNC is the combination of the "..configuration of assets, distribution of responsibilities, dominant management style, and ingrained organizational values" that a MNC has built up over time (Bartlett and Ghoshal, 1989: 41). The MNC's administrative heritage is the outcome of a combination of factors, including the company founder's ideology and beliefs, the company's history both at home and abroad, the composition of top management, etc. 
A MNC's HRM system is both influenced by and influences the administrative heritage of the firm. The firm's current HRM policies and practices are partially a product of the firm's history -- organizational learning from past successes and failures -- as well as a reflection of organizational norms, values, and goals, which are themselves reflective of the societal norms and values internalized by the founders and by generations of employees. Although MNCs may face similar environmental constraints, use similar technologies, and have equivalent experience in international operations, the companies' HRM competencies, because they are reflective of the firm's administrative heritage and unique past, are to some extent firm-specific (Bartlett and Ghoshal, 1989).

Although administrative heritage represents a complex system of values, structures and processes, one important component of the MNC's administrative heritage which will influence the transfer of HRM systems to foreign affiliates is the firm's overseas experience, both in terms of the length of time it has had overseas operations and its past successes or failures in the management of overseas affiliates.

MNCs with extensive experience overseas acquire information about the environments in which they do business. They learn through trial and error how to manage in different environments if they have effectively learned 
from their experiences. This process provides management with first-hand knowledge of differences between host and home country practices and norms, information concerning which parent company HRM policies and practices can be exported overseas and which cannot be used, as well as how to implement those HRM policies and practices most effectively, given the local environment. This leads us to predict that:

Proposition 3: The greater the MNC's experience in successfully transferring its HRM systems overseas, the more likely the parent firm will transfer its HRM system to its overseas affiliates.

Although it pays a key role, prior experience is not the only important dimension of administrative heritage influencing the transfer of the parent company HRM policies and practices overseas. Another important component of the administrative heritage of a firm is the strength of its corporate philosophy and management's belief that the MNC's overseas subsidiaries should adopt the parent company's management philosophy. At Procter \& Gamble, for example, HQs management's belief in the company's way of doing things was so strong that each overseas subsidiary was set up as a miniature replica of the U.S. corporation (Bartlett and Ghoshal, 1989: 38). P\&G believed that the parent's HRM system represented a distinctive competence that gave the firm a competitive edge vis a vis its competitors. 
Obviously such management beliefs on the part of parent company's management can lead a MNC to establish overseas HRM policies and practices which are similar to those in the parent company. This leads to the following proposition:

Proposition 4: The stronger the parent company management's belief that the firm's HRM system represents a distinctive competency, the more likely the parent firm will transfer its HRM system to its overseas affiliates.

\section{Host Country Characteristics}

In addition to MNC characteristics, the characteristics of the host country are of obvious importance in determining the characteristics of the overseas affiliate's HRM system. Such factors as the local labor market conditions, as well as the legal, political, and social environments, will influence what HRM philosophy, policies and practices are feasible or even allowable within a given environmental context. Subsidiaries operating in China, for example, face considerable difficulty in trying to incorporate parent company HRM practices and policies based on capitalistic assumptions into their systems (Von Glinow and Teagarden, 1990). In general, the more similar the host country and the home country characteristics, the easier it is for firms to transfer their HRM systems overseas. 
Although environments are multi-dimensional, for the purposes of this study, we focussed our attention on only one of these dimensions -- the cultural dimension of the environment. One of the most well-known and accepted definitions of this cultural dimension of the environment has been formulated by Hofstede (1984).

In a study of 160,000 IBM managers in over 60 countries, Hofstede (1984) found that cultures vary on four primary dimensions: individualism/collectivism, power distance, uncertainty avoidance, and masculinity/femininity. Individualism implies that people define themselves as individuals and organize into loosely knit social frameworks. On the other hand, collectivism implies that people define themselves in terms of their group membership and organize into tight social networks. Power distance measures the extent to which less powerful members of society accept the unequal distribution of power while uncertainty avoidance measures the extent to which people in a society feel threatened by ambiguous situations and the extent to which they try to avoid these situations. Finally, masculinity is defined as the extent to which the dominant values in society emphasize assertiveness and the acquisition of money and things, while downplaying relationships among people. Femininity, on the other hand, emphasizes relationships among people, concern for others, and the overall quality of life (Hofstede, 1984). 
Comparing Mexico, Japan, and the United States, Hofstede's research shows that Japanese are moderately high on power distance, moderate on individualism, very high on uncertainty avoidance and high on masculinity. Mexicans are very high on power distance, moderately low on individualism, moderately high on uncertainty avoidance, and moderately high on masculinity. Americans are moderately low on power distance, high on individualism, moderately-low on uncertainty avoidance and moderately high on masculinity. Looking across all four dimensions, there is greater cultural distance between the United States and Mexico than between Japan and Mexico, according to Hofstede's data $(1984)$

The smaller the cultural distance between the parent firm's home country and the affiliate's local environment, the fewer potential difficulties in transferring the parent company's HRM philosophy, policies, and practices to its overseas affiliates since the underlying values which form the foundation of the HRM system are similar across the two countries. This leads to the following proposition:

Proposition 5: Japanese firms, because of the smaller cultural distance between Japan and Mexico, will be more likely than American firms to transfer the parent's HRM system to their overseas affiliates. 
Outcome Measures: HRM and Overseas Affiliate Performance

The predictions outlined above focus on fits between the characteristics of the firm and the host country environment, but we have not yet considered the outcomes these fits have on the performance of the overseas affiliate. Using a systems approach we make the general prediction that:

Proposition 6: When the HRM system of the overseas affiliate fits with the characteristics of the MNC and its local environment, the affiliate will enjoy higher levels of performance than when the HRM system does not fit with these internal and external environments.

\section{Research Methodology}

The firms chosen for inclusion in this study are all maquiladoras located in Tijuana, Mexico. While Americans own the vast majority of maquiladoras in Mexico, approximately $80 \%$, Japan's investment in these facilities has been growing rapidly in recent years. There are approximately 200 Japanese maquiladoras and 1400 American maquiladoras operating in Mexico today (Scott and oseghale, 1990). A large number of these Japanese and American plants, approximately 650, are located in Tijuana. Eight Tijuana maquiladoras, four American and four Japanese, were examined in this study. Because this 
research was meant to be exploratory in nature, this sample provided a range of cases which could be studied in enough depth to discern both common patterns and significant differences. All but one of the maquiladoras is involved in electronics manufacturing. The exception, an American firm, is involved in miscellaneous manufacturing operations. By including both American and Japanese maquiladoras we are able to compare the international human resource management strategies of firms from countries with different cultural distances from Mexico, and with different traditions regarding the management of human resources. However, the study also focused on within-nationality as well as between-nationality differences to examine the impact of administrative heritage and parent companyaffiliate interdependence on the overseas affiliate's HRM system.

To test the propositions above, intensive face-to-face interviews at the eight maquiladoras, supplemented by written questionnaires, were used since a multi-method approach is appropriate in the theory building stage (Jick, 1984). Because the theoretical framework presented in this paper is a synthesis and extension of previous work in several areas (strategy, human resource management, international management), the case approach was used to provide a richer understanding of the applicability of the framework and the propositions derived from it. 
Case studies were carried out at each the eight sample maquiladoras through semi-structured interviews with each of the following persons: the managing director, the HRM director, two line managers, and three line operators. In some of the companies, a number of additional interviews were conducted with managerial personnel. In addition to the face-to-face interviews, the following materials were requested from each of the maquiladoras: an organization chart, copies of performance appraisal forms, a description of the maquiladora's selection procedures and criteria, copies of selection tests, new employee handbook, description of compensation system and benefits, and data on turnover during the last three years.

Written questionnaires were also developed for two groups of employees: top managers and line operators. For the top managers, a questionnaire focusing on strategy, HQsaffiliate interdependence, affiliate performance, and other variables of interest was developed by the authors. The questionnaire was first pilot-tested in Mexico and then distributed to all of the managing directors and to the HRM directors at each maquiladora in the sample. The managing directors and HRM directors at all eight firms in the sample returned completed questionnaires.

In addition, questionnaires were distributed to either all or a subset of the line workers (decision was made by the sample company) in seven of the eight maquiladoras in 
the study in order to measure employee satisfaction, commitment, and employees' perceptions of the differences between their maquiladora's HRM system and local Mexican practices.

The researchers took questionnaires for all line workers to the head of personnel in each maquiladora, who then passed them out to employees. Workers were told that their responses were confidential and would not be available to anyone in their company. They were instructed to deposit their completed questionnaires in a box set up in the company cafeteria. This box was picked up one week after questionnaire distribution by a Mexican research associate. Managers at the one firm that did not participate in the operator questionnaire portion of the study felt that it was not appropriate to do so since there were some labormanagement problems at the time the data were being collected.

Approximately 1300 operator questionnaires were left at the seven maquiladoras by the researchers and a total of 444 useable questionnaires were returned. Of these 444 respondents, 382 were operators and 52 were supervisors. On average, the operators at the maquiladoras have been with their firms for 22 months while the supervisors have been employed for an average of 41 months. The average age of the operators is 24 years while for supervisors it is 30 . 
Compared to the total population of workers in these firms, questionnaire respondents have been employed somewhat longer than average and are also somewhat older than the nonrespondents. In addition, although figures on literacy are not available from the companies, it is logical to assume that respondents have a higher rate of literacy then the nonrespondents in the study.

\section{Research Results and Discussion}

Basic descriptive information on the size, date of establishment, and other characteristics of the sample firms are presented in Table 1 below.

\section{TABLE 1 ABOUT HERE}

From Table 1 we see that the Japanese firms are, on average, larger in size and were established later than the American firms in the sample. This is consistent with trends of investment by these two countries in the maquiladoras: there were almost no Japanese firms in the maquiladora industry in Mexico until after 1986. Although Japanese investment in Mexico still remains at a relatively low level overall, those companies which have invested, including all of our sample firms, have made major 
investments. In terms of employment, for example, the Japanese maquiladoras in our sample are all large operations, with between 700 and 2000 employees.

on the other hand, American firms typically established small shelter operations in Mexico during the 1970's and then, if operations were successful, converted them into wholly-owned affiliates after a number of years of operating experience. Shelters are locally-owned maquiladoras with which firms contract for the manufacturing of the products, thus avoiding taking on the direct investment and management themselves. All of the American companies in our sample first established shelter operations in Tijuana in the $1970^{\prime} \mathrm{s}$ and then, in the mid- to late 1980's, converted them into wholly-owned maquiladoras. However, many of these American-owned firms are relatively small compared with their Japanese counterparts, with employment ranging from 97 to 1200 employees.

Looking at the total number of expatriates currently stationed in each of the maquiladoras, three of the four Japanese firms have 25 or more expatriates while only one American firm has 25 or more expatriates. Controlling for differences in size, we find that the proportion of expatriates to total employees in Japanese maquiladoras ranges from $.07 \%$ to $2.3 \%$ and from $0 \%$ to $5 \%$ in the American maquiladoras in the sample. According to interviews with managers at the maquiladoras, these figures have remained 
relatively constant over time, after the initial start-up period when a large number of expatriates were dispatched to set up the plants.

We also see from Table 1 that two of the Japanese maquiladoras are headed by a local national while two are headed by Japanese. In the American firms in the sample, three of the four maquiladoras are headed by an American.

Although there are some differences in staffing patterns between the Japanese and the American firms in the sample, interviews revealed that the nature of the expatriates and their roles in the organization vary greatly across companies, particularly when comparing the American to the Japanese maquiladoras.

The American firms in the sample have traditionally tended to use "ringers" -- Americans with no experience working for the parent firm who are hired in Mexico to run the plant. For example, firm A2, which has a very paternalistic orientation toward its workers, has been managed by a series of ringers since its establishment. The current managing director has no parent company experience but managers from the parent company frequently visit the maquiladora and are in constant contact with the managing director concerning all major decisions, and even many minor ones. Without using company-trained expatriates, the parent company has had moderate success in transferring HRM policies and practices to its maquiladora. 
Firm A4, on the other hand, has not used ringers in the management of its maquiladora but it has dramatically altered the kind of expatriate it sends overseas after disastrous performance in 1990. Until 1991, the parent company relied on American expatriates from the head office who had proven themselves in the domestic U.S. operation. In June, 1991, however, the firm replaced the top American at the maquiladora with a new American director who is more internationally experienced and culturally aware than his predecessors. This new director is actively attempting to transfer policies and practices, including those in HRM, from the parent company to the maquiladora but is adapting his style of implementation to fit with the local Mexican culture and environment.

This new managing director, unlike his predecessor and other Americans at the plant, was told by his American boss that in order to get the Tijuana assignment that he would have to learn Spanish. He enrolled in a two-month intensive Spanish-language program in the United States at company expense and since moving to Mexico has studied daily with a tutor. While we were visiting the plant, the managing director gave his first formal presentation to his Mexican staff -- in spanish. It is clear that although this firm still uses expatriates for its top maquiladora management positions, it is now attempting to train and assign managers 
who are capable of adapting parent company HRM practices and policies to fit with the local environment.

Although the Japanese firms in the sample do not tend to use ringers to run their maquiladoras, both $\mathrm{J} 1$ and $\mathrm{J} 3$ have hired Mexicans who have extensive previous experience in the maquiladora industry to run their operations. The primary differences between these individuals and those Mexican executives whom we interviewed in the American firms are that: 1) the Japanese firms hire only Mexicans with maquiladora experience, not other nationalities, such as Americans; 2) in the American firms ringers run the local operations after receiving approval via fax or telephone or mail from the head office in the United States, whereas in the Japanese firms, the Mexican managers work closely on the spot with top-level Japanese expatriates and decisions are made after much face to face discussion and negotiation; 3) ringers in the American maquiladoras are expected to move on after a certain period of time and have no long-term job security with the firm but the Mexican top managers in the Japanese firms are expected to stay with the maquiladora. Those firms which hire ringers but do not make them a permanent part of the organization are, in essence, limiting the amount of organizational learning which occurs while these executives are with the firm. Because ringers are outsiders who are expected to move on to another firm after they have successfully managed the maquiladora through a 
certain stage in its development, the knowledge and skills of these individuals do not become part of the organization's administrative heritage. Organizational learning can only occur in a partial fashion, often long distance, through conversations between company employees at the HQs and the locally hired executives. Even in those Japanese companies which integrate Mexican executives into the local organization, Mexicans are never rotated back to the HQs, and so their knowledge and skills do not build expertise at the head office.

However, the situation at some companies is changing. For example, until June, 1991, A3 was run by a long-term ringer who specialized in maquiladora management. In June, however, the parent company, in an effort to more closely integrate the Mexican operations into the American operations and to respond to severe industry changes, dispatched a young but very successful "company man" to head up the maquiladora. This maquiladora is currently in the midst of a fundamental shift in terms of both strategy and HRM system. At the same time, the parent company views its own HRM system as a liability rather than as a competence and is searching for other models, neither parent company nor local Mexican, to use in this change effort. The parent company is hoping to learn from the experiences of both its related company affiliates and its overseas affiliates, and to implement "best practices" from its far-flung operations 
in MNC headquarters. It is attempting to profit from knowledge, skills, and expertise developed around the world and therefore has begun a process of change so that the organizational learning process is not unidirectional but bi-directional -- both to and from the overseas affiliates.

It is also interesting to note that the Japanese firms which have hired local top managers and integrated them into the local organization have relatively higher levels of performance vis a vis the Japanese maquiladoras headed by Japanese nationals and all but one of the American maquiladoras in the sample. It is unclear, however, whether placing Mexicans into top executive positions within the maquiladoras has increased subsidiary performance or whether high levels of performance have given the firms the confidence to replace expatriates with local managers. Turning now to the propositions presented earlier in this chapter, we hypothesized in Proposition 1 that MNCs following a differentiation strategy will be more likely to transfer the HRM system of the parent company to their overseas affiliates than will MNCs following a cost strategy. Table 2 shows that three of the four Japanese firms in the sample are following predominantly a cost strategy while two of the American firms are following a cost strategy and two are following a differentiation strategy. It is important to point out here that although a number of maquiladoras in our sample are pursuing a 
differentiation strategy, interviews with the managing directors revealed that cost is still a major factor affecting all of their operations. All of the firms in our study are engaged in global industries and face severe cost pressure from competitors from lower-wage countries.

We see from Table 2 that, contrary to our prediction in Proposition 1, there does not seem to be a relationship between the MNC's strategy and the transfer of HRM overseas. J3 is the only Japanese firm with a differentiation strategy and, contrary to our prediction, this firm has a relatively low level of HRM transfer from the parent to the maquiladora. J1, J2 and $\mathrm{J} 3$ are all following a cost strategy and have high levels of HRM transfer. For the Japanese firms in our sample, it appears that firms following a cost strategy are, contrary to our prediction, more likely to transfer the firm's HRM system overseas than those Japanese firms following a differentiation strategy. Interviews with top managers confirms that Japanese managers in the high-transfer firms believe that using HRM systems developed in Japan contribute to lower costs.

Among the American firms, on the other hand, firms A1 and A4 are following a cost strategy and have medium to low transfers whereas firms $A 2$ and $A 3$ are following a differentiation strategy and also have medium to low HRM transfers. For the American maquiladoras in our sample, MNC 
strategy does not seem to have an impact on the transfer of the parent's HRM system overseas.

Proposition 2 stated that the higher the interdependence between the parent company and the overseas affiliate, the more likely the parent company will be to transfer its HRM system to its overseas affiliate. The nature of our sample would lead us to assume that, on the basis of maquiladora size alone, that the American MNCs should be far less dependent on their operations than are the Japanese MNCs. However, in questionnaires filled out by top management, all respondents indicated that interdependence is high, except in the case of firm A2, where interdependence is low (see Table 2 below). This maquiladora currently has only 97 employees, down from over 200 employees less than one year ago. Although this firm has been operating in Mexico for over 31 years, the current American recession has significantly reduced the need for overseas assembly and operations have been largely centralized at the parent company.

In addition, in all of the firms except A2, managers stated in interviews that the level of interdependence between their parent company and the maquiladora was high and was likely to increase in the future. For example, both J1 and J2 were adding new product lines from the United states to their maquiladora operations during our field visit in August, 1991. It was clear from interviews that 
these new product lines would serve to increase further the level of interdependence between not only the Japanese parent firms and their maquiladoras, but also between the Japanese firms' American affiliates and the maquiladoras.

Although none of the American firms were in the process of adding additional production, interviews at the two largest American maquiladoras revealed that global rationalization, brought on by severe economic conditions, particularly in the United States, was increasing. As part of this rationalization process, integrating mechanisms were being implemented between not only the parent firm and the maquiladora, but between the maquiladora and other overseas operations, in order to reduce duplication and lower costs. Even in the smaller American maquiladoras the managing directors told us that their maquiladoras depended almost exclusively on the parent company for production inputs, technology, and management systems while the parent company was highly dependent on the maquiladoras for finished products for the American market.

Because all but one of the managing directors stated that their firms are highly integrated, we cannot directly address Proposition 2. However, it is clear that interdependence is not a determining factor in this sample in whether HRM is transferred overseas from the parent company or not -- some firms with high levels of interdependence transfer their systems while others adapt to 
the local norms. Thus, for these firms, interdependence does not differentiate between firms which transfer HRM systems overseas and those which adapt to local practices, contrary to our prediction.

TABLE 2 ABOUT HERE

Turning now to a firm's past experience, Proposition 3 states that the greater the MNC's past experience in successfully transferring its HRM systems overseas, the more likely the parent firm will be to transfer its HRM system to its overseas affiliates. The four Japanese parent firms in our sample all have extensive international experience in a wide range of countries. The American firms, on the other hand, are mixed. All of the American parent firms, except for A1, do have a number of overseas affiliates around the world. However, these American overseas operations are generally on a smaller scale than those of their Japanese counterparts.

Despite the differences between the Japanese and the American firms in the sample, our interviews with top managers in the maquiladoras indicate that previous international experience in general is not a particularly important factor in determining whether top management at the parent company attempts to transfer its HRM practices 
and policies overseas. Experience in Mexico, on the other hand, does seem to have some impact, with the American firms more likely to make dramatic adaptations in the face of transfer failure and the Japanese firms to make gradual adaptations.

In general, we found that for the American firms in the sample, past negative experiences in transferring the parent company system overseas led to an emphasis on local adaptation, which was reflected both in company policies and practices as well as management philosophy. For example, firm $A 1$ is a fairly small firm and has only one overseas operation. Its negative experiences in trying to transfer the American parent company's HRM system to Mexico a number of years ago led to its current policy of adopting local HRM policies and practices. This maquiladora currently does not have a single expatriate in its Tijuana plant and the Mexican managing director is insistent that the firm be run as a Mexican company.

For the Japanese companies, on the other hand, past negative experiences have led some firms (J3, and to some extent J1), to adapt to Mexican practice while for other firms (J2 and J4), past negative experiences have led to greater efforts to transfer the parent company's system overseas. As discussed in further detail below, it appears that when management believes that the parent company's HRM system represents a distinctive competency, they persist in 
their attempts to transfer HRM overseas, even in the face of failure. Thus, international experience does not have a consistent effect on transfer of the MNC's HRM system to its maquiladoras.

Although it plays a key role, prior experience is not the only important dimension of administrative heritage influencing the transfer of the parent company HRM policies and practices overseas. Another important component of the administrative heritage of a firm is the strength of its corporate philosophy and management's belief that the MNC's overseas affiliates should adopt the parent company's management philosophy.

From Table 2 we see that there is strong support for the proposition that the stronger the parent company management's belief that the firm's HRM system represents a distinctive competency, the more likely the parent firm will be to transfer its HRM system to its overseas affiliates. In fact, of all of the factors which we examined in this study, including previous experience, corporate strategy, nationality of the parent firm, etc., the belief that HRM represents a distinctive competitive advantage for the MNC came out again and again in our interviews as the most important reason why a firm did or did not attempt to transfer its parent company's HRM system overseas. Whether transfer has been successful in the past or not, top management's belief that the parent company's HRM system is 
a distinctive competency appears to drive the transfer of the parent company system overseas.

This finding does not merely represent firm differences in success of transfer, for there are firms in the sample which have not been successful using home country HRM policies and practices overseas yet continue to try to apply them. Firm J2, for example, has over 11 years of experience in Tijuana yet because it cannot make Japanese policies and practices work effectively, managers complained that the local workforce was the source of all of their problems, not the firm's management style or practices. At $\mathrm{J} 1$, workers were keenly aware of the strong, consistent desire of the Japanese managers to operate the maquiladora as though it were located in Japan. One line worker commented that: "...If it were left up to them (the Japanese managers), everyone would work like a Japanese. They wish we were Japanese. They have Japanese rules." This employee's view was shared in interviews with other workers who indicated that the HRM system in this plant was becoming more Japanese over time.

In addition to firm-specific characteristics, we proposed in Proposition 5 that Japanese firms in general, because of the smaller cultural distance between Japan and Mexico, will be more likely than American firms to transfer the parent company's HRM system to its overseas affiliates. 
While three of the four Japanese firms score low on adaptation to Mexican HRM policies and practices, three of the four score high on their level of HRM transfer from the parent company. At the same time, three of the four American firms have medium to high levels of adaptation while two have moderate levels of transfer and two of the maquiladoras have low levels of HRM transfer from the parent company. The results thus support our prediction, although our interviews uncovered an interesting caveat to these results.

While we originally assumed that absolute differences in cultural distance would be consistent with perceived cultural differences, we consistently found in our interviews with Mexican managers and operators that the Mexican perception is that Japanese and Mexican cultures are much further apart than are American and Mexican cultures. At the same time, a number of Japanese managers were quick to point out similarities between Japanese and Mexican cultural values.

Actual cultural distance may predict whether a MNC attempts to transfer its HRM policies and practices overseas. At the same time, it may be that "perceived" cultural distance, regardless of "actual" cultural distance may be the more important factor in predicting how local employees will react to those policies and practices. Interviews revealed that Mexican managers and operators 
attributed most of their dissatisfaction with Japanese policies and practices to "cultural differences." Although we did not measure respondents' perception of cultural distance directly in this study, it may be a lack of familiarity, rather than cultural distance per se, which is most important in determining local employees' reactions to the transferred management system.

Finally, Proposition 6 predicts that when the HRM system of an overseas affiliate fits with the characteristics of the MNC and its local environment, the affiliate will enjoy higher levels of performance than when the HRM system does not fit with these internal and external environments. Looking first at the individual performance measures of organizational commitment and satisfaction of employees in the Japanese and American maquiladoras in the sample, we see from Table 3 that on the whole, Mexican workers in American maquiladoras are significantly more satisfied and committed to their firms than are Mexican workers in Japanese maquiladoras.

At the same time, there is a significant difference between respondents in Japanese and American firms in how similar they perceive their companies to be to Mexican firms in general (see Table 3). Overall, Mexicans in American firms believe that their companies are more "Mexican" than do respondents in Japanese maquiladoras. Comparing individual firms, however, a Japanese firm, J3, enjoys the 
highest levels of employee commitment and satisfaction and employees at this maquiladora perceive it to be fairly "Mexican" in management approach. These results indicate that it is not the nationality of the maquiladora which is important, but certain management practices employed by individual Japanese firms which result in low levels of employee satisfaction and commitment among Mexican workers. Although it is impossible to determine causality in this study, our interviews lead us to believe that these results indicate that the transfer of Japanese HRM practices to the maquiladora, in the face of large perceived cultural differences, negatively impacts on the satisfaction and commitment of Mexican employees.

\section{TABLE 3 ABOUT HERE}

However, the lower levels of satisfaction and commitment of the Mexican workers in all of the Japanese firms except for J3 does not appear to be associated with higher levels of turnover in the Japanese firms in our sample (see Table 2). From a manager's point of view, the important question may be whether the lower satisfaction in most of the Japanese maquiladoras impacts on job performance. Prior research in the U.S. indicates that the relationship is not always that strong (e.g., Mobley, 1980), 
and in our data, there is no obvious relationship between maquiladora performance as reported by the managers and satisfaction or commitment of the operators. Interviews with the operators themselves, however, indicated that their lower satisfaction levels are associated with low morale and a sense of resentment toward the Japanese managers in the maquiladoras.

In terms of affiliate-level performance, which was measured in written questionnaires and interviews with maquiladora managers, we find that overall, most of the maquiladoras are performing at a level consistent with their local competitors, while two of the firms, one Japanese (J3) and one American (A1) are performing well above average.

Out of all of the firms in the sample, J3 seems to be enjoying the highest performance, in relation to the performance of other maquiladoras, other subsidiaries of the parent firm, and vis a vis HQs expectations for the maquiladora. J3 also enjoys the highest levels of employee satisfaction and commitment among the eight firms in the sample, has adapted its HRM practices and policies to local norms to a moderate extent, and has not transferred its Japanese HRM system overseas but has attempted to use a number of practices and policies in Mexico which were developed in its American subsidiary. Although J3 has only had six years of experience in Mexico, the parent company does have extensive international experience in a large 
number of countries. In addition, although managers we interviewed at $\mathrm{J} 3$ do not believe that the parent company's HRM system is a source of distinctive competence per se, they do believe in an internationalized HRM system. This hybrid maquiladora, combining characteristics of Japanese, American, and Mexican systems has thus far been relatively successful in terms of both employee and maquiladora-level performance.

A2, the other high performing maquiladora in our sample, has much longer experience in Mexico -- 19 years. Although its performance is high, this maquiladora may well go out of business as operations are consolidated in the United states. Although it is less expensive to produce the company's products in Tijuana, because this firm has a "family" corporate culture, the top management is letting the Mexican workforce decline through attrition in order to maintain employment in the United states. The future of this maquiladora depends not on its relative success in Tijuana but on how well the American economy does in the next 12 months. 


\section{summary and Conclusions}

Taking the results together, there are significant differences between the American and Japanese maquiladoras in our sample in a number of areas. First, while none of the managers at the American maquiladoras believed strongly that the parent company's HRM system was a distinctive competence, managers at three of the four Japanese maquiladoras did. Furthermore, as stated above, a belief in the parent's HRM competence seems related to high levels of HRM transfer from the parent company to the maquiladora. This finding certainly confirms the numerous reports of the ethnocentric approach of Japanese firms to their overseas operations (e.g., Fucini and Fucini, 1990), in which there is an attempt to mold the overseas subsidiary into as close a replica of the home plants as possible, at least with regard to management practices. It is telling that the workers in the Japanese maquiladoras which used such an approach were less satisfied and committed than those working for American firms.

It is neither the pure American nor the pure Japanese approach which is most successful in the Tijuana maquiladora context but the hybrid organization of J3 which has achieved relative success in balancing both internal and external consistency demands. This firm enjoys high levels of employee commitment and satisfaction, as well as a high 
level of subunit-level performance. Although we cannot rule out the possibility that other factors not measured in this study are responsible for these results, interviews with J3 managers, workers, and competitors all point to the hybrid HRM system as the key to its success in Mexico.

For the Japanese firms in the study, with the exception of J3, lower levels of individual and maquiladora performance may be outweighed by the cost savings of operating in Mexico in the short run. However, as more and more companies continue to invest in Mexico, there will be greater competition at the firm level and greater competition for the loyalties of the local workforce. Those firms which, through appropriate HRM policies and practices, are better able to attract and retain the local workforce will gain a competitive advantage over those firms which cannot. This is not to say that firms should forego internal consistency in favor of external consistency but that, in the long-run, competitive conditions will require both high levels of internal and external consistency which allow the MNC to simultaneously integrate and differentiate its operations around the world, and therefore meet the demands of a globalized economy (Bartlett and Ghoshal, 1989; Ghadar \& Adler, 1989).

At the same time, those firms which hire local executives for the long-term and integrate them into the organization, will facilitate organizational learning and 
the creation of an administrative heritage which both reflects the values and norms of the home country, as well as those of the host country. Organizational learning, whether it occurs in Mexico, Indonesia, or Spain, will facilitate the globalization of MNCs and move corporations out of the third phase of internationalization into the fourth phase.

In this new stage, the focus of Japanese corporate strategy will shift away from the localization of production to an emphasis on balancing localization and global integration (Bartlett and Ghoshal, 1989). A complex and sophisticated HRM system which can effectively utilize the human resources in the organization, regardless of their nationality, and create not only global products but global mind sets, will be an essential competency for the transnationals which leading the way into the 21 st century. 


\section{ACKNOWLEDGEMENTS}

An earlier version of this paper was presented at the 1992 annual meeting of the Association for Japanese Business Studies in Denver, Colorado. We would like to gratefully acknowledge the assistance of Debbie Adams at Portland state University and Lic. G. Enrique Nunez Hurtado, Director of Education at Centro de Ensenanza Tecnica y Superior, Tijuana, Mexico. This research was supported by the Management Institute at Columbia Business School and Corporate Associates Summer Research Fund at Portland state University Business School. 


\section{REFERENCES}

Adler, Nancy. (1991) International Dimensions of Organizational Behavior (2nd edition). Boston: PWS-Kent.

Bartlett, Christopher. (1986) "Building and Managing the Transnational: The New Organizational Challenge." In

M. Porter (ed.) Competition in Global Industries. Cambridge, MA: Harvard University Press, pp. 367-404.

Bartlett, Christopher and Sumantra Ghoshal. (1989) Managing Across Borders. Boston: Harvard University Press.

Businessweek. (1990) "Mexico: A New Economic Era." November $12: 102-113$.

Butler, John, G. Ferris, and N. Napier. (1990) strategy and Human Resources. Cincinnati: South-Western Publishing Co.

Caves, Richard. (1982) Multinational Enterprise and Economic Analysis. London: Cambridge University Press.

Doz, Yves. (1986) strategic Management in Multinational Companies. Oxford: Pergamon Press. 
Evans, Paul. (1986) "The Strategic Outcomes of Human Resource Management." Human Resource Management, Spring: 149-167.

Fucini, J. J. and Suzy Fucini. (1990) Working for the Japanese. New York: The Free Press.

Ghoshal, Sumantra and Christopher Bartlett. (1988) "Creation, Adoption, and Diffusion of Innovations by Subsidiaries of Multinational Corporations." Journal of International Business Studies, Fall: 365-388.

Hofstede, Geert. (1984) Culture's Consequences:

International Differences in Work Related Values. Beverly Hills: Sage Publications.

Inohara, H. (1990) Human Resource Development in Japanese Companies. Tokyo: Asian Productivity Organization.

Jick, Todd. (1984) "Mixing Qualitative and Quantitative Methods: Triangulation in Action." In T. Bateman and G. Ferris (eds.) Methods and Analysis in Organizational Research, Reston, VA: Reston Publishing Co. 
Milliman, John, Mary Ann Von Glinow, and Maria Nathan.

(1991) "Organizational Life Cycles and strategic

International Human Resource Management in Multinational

Companies: Implications for Congruence Theory." Academy of Management Review, Vol. 16, No. 2: 318-339.

Mobley, William H. (1982) Employee Turnover: Causes, Consequences, and Control. Reading, MA: Addison-Wesley.

Napier, Nancy. (1990) "Strategy, Human Resources Management, and organizational outcomes: Coming out from Between the cracks." In G. Ferris, K. Rowland, and M. Buckley (eds.) Human Resources Management: Perspectives and Issues. Boston: Allyn and Bacon, pp. 16-22.

Porter, Michael E. (1986) "Competition in Global Industries: A Conceptual Framework." In M. Porter (ed.) Competition in Global Industries. Cambridge, MA: Harvard University Press, pp. $15-60$.

Pucik, Vladimir. (1985) "Strategic Human Resource Management in a Multinational Firm." In H.V. Wortzel and L.H. Wortzel (eds.) Strategic Management of Multinational Corporations. New York: John Wiley, pp. 424-434. 
Schneider, Susan. (1990) "National vs. Corporate Culture: Implications for Human Resource Management." In M. Mendenhall and G. Oddou (eds.) International Human Resources Management. Boston: PWS-Kent, pp. 13-27.

Schneider, Benjamin and Neal Schmitt. (1986) staffing Organizations. Glenview, IL: Scott, Foresman and Co.

Scott, C. and B. Oseghale. (1990) "Japanese Maquiladoras: Threat to the Border Industrialization Program." American Business Review, January: 55-60.

Taylor, Sully, Schon Beechler, and Dick Moxon. (1991) "The Transfer of HRM Competence to Japanese and American Maquiladoras: A Research Proposal." Paper presented at the Association of Japanese Business Studies Meeting, Honolulu, Hawaii.

Teagarden, Mary, Mark Butler, \& Mary Ann Von Glinow. (1992) "Mexico's Maquiladora Industry: Where Strategic Human Resource Management Makes a Difference." Organizational Dynamics, winter: 34-47.

Ulrich, Dave and Dale Lake. (1990) Organizational Capability. New York: John Wiley and Son. 
Van de Ven, Andrew \& Robert Drazin. (1985). "The Concept of Fit in Contingency Theory." Research in Organizational Behavior 7: 333-365.

Von Glinow, Mary Ann, and Mary Teagarden. (1990) "The Transfer of Human Resource Management Technology in Sino-U.S. Cooperative Ventures: Problems and Solutions." In M. Mendenhall and G. Oddou (eds.) International Human Resources Management. Boston: PWS-Kent, pp. 301-325. 
Table 1: Maquiladora Characteristics

\begin{tabular}{|c|c|c|c|c|c|c|}
\hline Firm & $\begin{array}{l}\text { Parent } \\
\text { Nationality }\end{array}$ & $\begin{array}{l}\text { Year } \\
\text { Maquiladora } \\
\text { was } \\
\text { Established }\end{array}$ & $\begin{array}{l}\text { Total \# of } \\
\text { Employees in } \\
\text { Maquiladora }\end{array}$ & $\begin{array}{l}\text { Nationality of } \\
\text { Maquiladora } \\
\text { President/ } \\
\text { Director }\end{array}$ & $\begin{array}{l}\text { Number of } \\
\text { American/ } \\
\text { Japanese } \\
\text { Dispatchees }\end{array}$ & $\begin{array}{l}\text { Type of } \\
\text { Product } \\
\text { Assembled }\end{array}$ \\
\hline J1 & Japanese & 1982 & 2000 & Mexican & 28 & $\begin{array}{l}\text { consumer } \\
\text { electronics }\end{array}$ \\
\hline $\mathrm{J} 2$ & Japanese & 1980 & 1250 & Japanese & 25 & $\begin{array}{l}\text { consumer } \\
\text { electronics }\end{array}$ \\
\hline J3 & Japanese & 1985 & 1600 & Mexican & 36 & $\begin{array}{l}\text { consumer } \\
\text { electronics }\end{array}$ \\
\hline $\mathrm{J} 4$ & Japanese & 1986 & 700 & Japanese & 5 & $\begin{array}{l}\text { consumer } \\
\text { electronics }\end{array}$ \\
\hline A1 & American & $\begin{array}{l}1983 \\
(1972)^{*}\end{array}$ & 550 & Mexican & 0 & $\begin{array}{l}\text { consumer } \\
\text { electronics }\end{array}$ \\
\hline $\mathrm{A} 2$ & American & $\begin{array}{l}1985 \\
(1960) *\end{array}$ & 97 & American & 3 & electronics \\
\hline A3 & American & $\begin{array}{l}1988 \\
(1977)^{*}\end{array}$ & 500 & American & 25 & electronics \\
\hline A4 & American & $\begin{array}{l}1983 \\
(1979) *\end{array}$ & 1200 & American & 10 & $\begin{array}{l}\text { consumer } \\
\text { goods }\end{array}$ \\
\hline
\end{tabular}

*Actual year operations were established in Tijuana (as a shelter operation). 
Table 2: Parent Company Characteristics, Maquiladora Characteristics, and Performance Results

\begin{tabular}{|c|c|c|c|c|c|c|c|c|c|c|c|}
\hline Firm & $\begin{array}{l}\text { MNC } \\
\text { Strateg- } \\
\text { ic Focus }\end{array}$ & $\begin{array}{l}\text { Level of } \\
\text { Parent- } \\
\text { Affiliate } \\
\text { Inter- } \\
\text { depen- } \\
\text { dence }\end{array}$ & $\begin{array}{l}\text { \# Years } \\
\text { Experi- } \\
\text { ence in } \\
\text { Mexico }\end{array}$ & $\begin{array}{l}\text { HRM } \\
\text { Transfer } \\
\text { Success }\end{array}$ & $\begin{array}{l}\text { Belief } \\
\text { that } \\
\text { Parent } \\
\text { HRM is } \\
\text { a } \\
\text { Compe- } \\
\text { tence }\end{array}$ & $\begin{array}{l}\text { Level of } \\
\text { HRM } \\
\text { Adapta- } \\
\text { tion to } \\
\text { Mexico }\end{array}$ & $\begin{array}{l}\text { Level of } \\
\text { HRM } \\
\text { Transfer } \\
\text { from } \\
\text { Parent }\end{array}$ & $\begin{array}{l}\text { Employ- } \\
\text { ee } \\
\text { Satisfac- } \\
\text { tion }^{1}\end{array}$ & $\begin{array}{l}\text { Employ- } \\
\text { ee } \\
\text { Commit } \\
\text {-ment }{ }^{2}\end{array}$ & $\begin{array}{l}\text { Employ- } \\
\text { ee Turn- } \\
\text { over } \\
\text { (ave. \% } \\
\text { per } \\
\text { month) }\end{array}$ & $\begin{array}{l}\text { Overall } \\
\text { Maqui- } \\
\text { ladora } \\
\text { Perfor- } \\
\text { mance }\end{array}$ \\
\hline $\mathrm{J} 1$ & Cost & High & 9 & $\begin{array}{l}\text { Moder- } \\
\text { ate }\end{array}$ & High & Low & High & 3.18 & 4.55 & $07 \%$ & $\begin{array}{l}\text { Moder- } \\
\text { ate }\end{array}$ \\
\hline $\mathbf{J} 2$ & Cost & High & 11 & $\begin{array}{l}\text { Moder- } \\
\text { ate }\end{array}$ & High & Low & High & $--^{3}$ & $--^{3}$ & $10 \%$ & $\begin{array}{l}\text { Moder- } \\
\text { ate }\end{array}$ \\
\hline J3 & $\begin{array}{l}\text { Differ- } \\
\text { entiation }\end{array}$ & High & 6 & $\begin{array}{l}\text { Moder- } \\
\text { ate }\end{array}$ & Low & $\begin{array}{l}\text { Moder- } \\
\text { ate }\end{array}$ & Low & 4.02 & 5.48 & $09 \%$ & High \\
\hline $\mathrm{J} 4$ & Cost & High & 5 & $\begin{array}{l}\text { Moder- } \\
\text { ate }\end{array}$ & High & Low & High & 3.21 & 4.17 & NA & $\begin{array}{l}\text { Moder- } \\
\text { ate }\end{array}$ \\
\hline A1 & Cost & High & 19 & Low & Low & High & $\begin{array}{l}\text { Moder- } \\
\text { ate }\end{array}$ & 3.66 & 4.83 & $16 \%$ & High \\
\hline $\mathrm{A} 2$ & $\begin{array}{l}\text { Differ- } \\
\text { entiation }\end{array}$ & Low & 31 & $\begin{array}{l}\text { Moder- } \\
\text { ate }\end{array}$ & $\begin{array}{l}\text { Moder- } \\
\text { ate }\end{array}$ & $\begin{array}{l}\text { Moder- } \\
\text { ate }\end{array}$ & $\begin{array}{l}\text { Moder- } \\
\text { ate }\end{array}$ & 3.50 & 4.49 & $07 \%$ & $\begin{array}{l}\text { Moder- } \\
\text { ate }\end{array}$ \\
\hline A3 & $\begin{array}{l}\text { Differ- } \\
\text { entiation }\end{array}$ & High & 14 & Low & Low & Low & Low & 3.39 & 4.67 & $06 \%$ & $\begin{array}{l}\text { Moder- } \\
\text { ate to } \\
\text { High }\end{array}$ \\
\hline A4 & Cost & High & 12 & Low & Low & $\begin{array}{l}\text { Moder- } \\
\text { ate }\end{array}$ & Low & 3.68 & 4.82 & $15 \%$ & $\begin{array}{l}\text { Moder- } \\
\text { ate to } \\
\text { High }\end{array}$ \\
\hline
\end{tabular}

${ }^{1}$ Satisfaction was measured in questionnaires to supervisors and operators and was measured on a 5-point Likert scale. The higher the number, the higher the level of employee satisfaction.

${ }^{2}$ Commitment was measured in questionnaires to supervisors and operators and was measured on a 7-point Likert scale. The higher the number, the higher the level of employee commitment to the maquiladora.

${ }^{3}$ Questionnaires were not distributed in this maquiladora. 
Table 3: Results of T-Tests for Differences On Measures of Satisfaction, Commitment, and Similarity Between Japanese and American Maquiladoras

$\begin{array}{lll}\text { SATISFACTION } & \text { COMMITMENT } & \text { SIMILARITY } \\ & \text { TO MEXICAN } \\ & \text { PRACTICE }\end{array}$

JAPANESE

FIRMS

$3.25 * * *$

4.58*

$4.05 * * *$

AMERICAN

FIRMS

3.60

4.74

4.56

$* * * \mathrm{P}<.00$

$* * \mathrm{P}<.05$

$* \quad \mathrm{P}<.10$

Results are from questionnaires distributed to supervisors and operators in seven of the eight sample maquiladoras. Total number of respondents $=444$. 